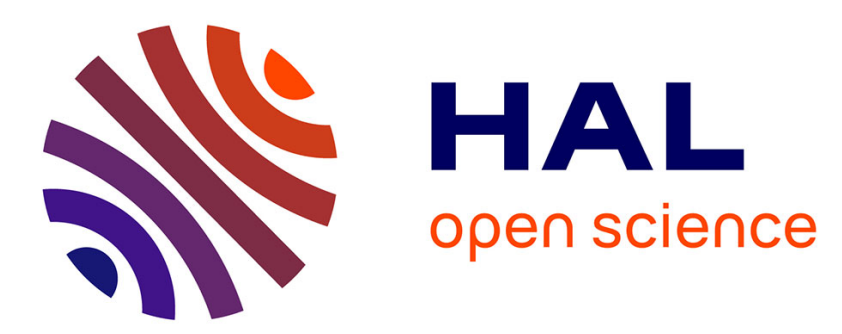

\title{
The right of resistance in Richard Price and Joseph Priestley
}

Rémy Duthille

\section{To cite this version:}

Rémy Duthille. The right of resistance in Richard Price and Joseph Priestley. History of European Ideas, 2018, pp.1 - 14. 10.1080/01916599.2018.1473957 . hal-01845996

\section{HAL Id: hal-01845996 \\ https://hal.science/hal-01845996}

Submitted on $20 \mathrm{Jul} 2018$

HAL is a multi-disciplinary open access archive for the deposit and dissemination of scientific research documents, whether they are published or not. The documents may come from teaching and research institutions in France or abroad, or from public or private research centers.
L'archive ouverte pluridisciplinaire HAL, est destinée au dépôt et à la diffusion de documents scientifiques de niveau recherche, publiés ou non, émanant des établissements d'enseignement et de recherche français ou étrangers, des laboratoires publics ou privés. 


\section{The right of resistance in Richard Price and Joseph Priestley}

\section{Rémy Duthille}

Published online: 20 Jun 2018

Rémy Duthille (2018) The right of resistance in Richard Price and Joseph Priestley, History of European Ideas, DOI: 10.1080/01916599.2018.1473957

\section{ABSTRACT}

This article is concerned with the writings on resistance by Richard Price and Joseph Priestley, the leaders of the Rational Dissenters who supported the American and French Revolutions, from the late 1760s to 1791 . The article discusses the differences between Rational Dissent and mainstream (Court) Whig resistance theory, as regards history in particular: the Dissenters viewed the Glorious Revolution as a lost opportunity rather than a full triumph and claimed the heritage of the Puritan opposition to Charles I, some of them justifying the regicide. Price's and Priestley's views on resistance are assessed against the benchmark of John Locke's conception of the breach of trust. While both thinkers presented themselves as followers of Locke, they departed from his thought by their emphasis on the constantly active role of the people. Each in their own way, they also argued that early, possibly peaceful, resistance was preferable to violent resistance as a last resort against a tyranny. In the end, Price and Priestley articulated each an original theory derived from Locke; their views were very close and their main difference concerned the treatment of history, Price's caution contrasting with Priestley's justification of tyrannicide.

\section{KEYWORDS:}

$\underline{\text { Resistance, }} \underline{\text { Price, }}$ Richard, Priestley, Joseph, revolution, dissenters, Locke, John

Ever since their own lifetimes, Richard Price (1723-1791) and Joseph Priestley (1733-1804) have been recognized as the intellectual luminaries of Dissent in the early reign of George III. ${ }^{1} 1$ The standard works on Dissent are Michael Watts, The Dissenters, 2 vols (Oxford: Oxford University Press, 1978-1995), and James Bennett, History of Dissenters, from the Revolution in 1688 to the Year 1808, 4 vols (London, 1808-1812). There are two biographies of Richard Price: D.O. Thomas, The Honest Mind: The Thought and Work of Richard Price (Oxford: Clarendon, 1977) and Paul Frame, Liberty's Apostle: Richard Price, His Life and Times (Cardiff: University of Wales Press, 2015). On Priestley, see Robert Schofield, The Enlightenment of Joseph Priestley: A Study of his Life and Work from 1733 to 1773 (University Park: Pennsylvania State University Press, 1997) and The Enlightened Joseph Priestley: A Study of His Life and Work from 1773 to 1804 (University Park: Pennsylvania State University Press, 2004).View all notes They were at the vanguard of a group that supported the American colonists' resistance to the mother country, loudly opposed the American War and welcomed the French Revolution, at least in its early stages. 22 On the American War, see James E. Bradley, Religion, Revolution and English Radicalism: Nonconformity in Eighteenth-Century Politics and Society (Cambridge: Cambridge University Press, 1990). Bradley discusses Dissenting ministers' defence of the right of resistance during the American War (154-8) and Price's influence over some of them (134). On the reception of the French Revolution and the opposition to the French Wars: J.E. 
Cookson, The Friends of Peace. Anti-war Liberalism in England, 1793-1815 (Cambridge: Cambridge University Press, 1982).View all notes The Rational Dissenters were a minority within the English Dissenters, which itself accounted for no more than $6 \%$ of the English population by the late eighteenth century. They were, however, a very vocal group and in many ways an advanced intellectual phalanx inside Dissent. ${ }^{3} 3$ The Rational Dissenters rejected Calvinism and its account of the fall of man and the need for regeneration. They embraced Unitarianism (like Priestley at the end of his life) or were on the road to it (like Price, an Arian). Knud Haakonssen, 'Enlightened Dissent: An Introduction', in Enlightenment and Religion: Rational Dissent in Eighteenth-Century Britain, ed. Knud Haakonssen (Cambridge: Cambridge University Press, 1996), 4.View all notes In the broader context of the European Enlightenment, or Enlightenments, they are probably the best candidates for a British strand of a 'radical' enlightenment, one that had connections with the continent and that belied interpretations presenting eighteenth-century England as a hegemony of conservative forces. ${ }^{4} 4$ Jonathan Israel places Richard Price, Joseph Priestley, John Jebb, William Godwin and Mary Wollstonecraft within the 'radical Enlightenment' in Democratic Enlightenment: Philosophy, Revolution, and Human Rights 1750-1790 (Oxford: Oxford University Press, 2011). See also Anthony Page, John Jebb and the Enlightenment Origins of British Radicalism (Westport, CT: Praeger, 2003).View all notes Rational Dissent is significant in the history of resistance because it articulated a new conception of the right of resistance that broke away with conceptions that had been current in England since the Glorious Revolution of 1688-1689.

This article examines pamphlets and sermons from 1768, the date of Priestley's first important statement on resistance, to 1791. This date corresponds roughly to the end of the early reception of the French Revolution (the publication of the first part of Thomas Paine's Rights of Man in March 1791 can be considered a turning point), and especially to the waning of Price's and Priestley's influence. The first died in April 1791, and the second saw his house and scientific apparatus destroyed on 14 July 1791 during the so-called Priestley Riots, a tragic episode which led him to emigrate to Pennsylvania in April 1794. From 1768 to 1791, Price and Priestley were at the forefront of the Dissenters' repeated campaigns for the repeal of the Test and Corporation Acts. They became notorious and attracted much opprobrium and controversy on themselves for defending the American colonists. The two men are still often mentioned together given the friendship that united them, the common causes they engaged in, and the proximity of their views on the American War, civil liberty, and the separation of church and state. Their contemporaries already joined them together, for the same reasons, and they themselves had encouraged this coupling when they famously made a show of intellectual candour in agreeing to disagree on metaphysical matters. .5 Joseph Priestley and Richard Price, A Free Discussion of the Doctrines of Materialism, and Philosophical Necessity, in a Correspondence between Dr. Price, and Dr. Priestley. To Which Are Added, By Dr. Priestley, An Introduction, Explaining the Nature of the Controversy, and Letters to Several Writers Who Have Animadverted on his Disquisitions Relating to Matter and Spirit, or his Treatise on Necessity (London, 1778). View all notes This article sets out to compare Price's and Priestley's conceptions of resistance, which have been studied separately. 6 James Caudle, 'Richard Price and the Revolution in Resistance Theory, 1770-1790', Consortium on Revolutionary Europe 1750-1850: Selected Papers (Tallahassee, FL: Institute on Napoleon and the French Revolution, Florida State University, 2000), 55-66; Martin Fitzpatrick, 'Joseph Priestley, Political Philosopher', in Joseph Priestley, Scientist, Philosopher, and Theologian, ed. Isabel Rivers and David L. Wykes (Oxford: Oxford University Press, 2008), 116-18.View all notes H.T. Dickinson discussed both thinkers in terms of a radicalization of Locke's political theory. ${ }^{7} 7$ H.T. Dickinson, Liberty and Property: Political Ideology in 
Eighteenth-Century Britain (London: Weidenfeld and Nicolson, 1977), 197-9.View all notes This point of view is especially relevant as Priestley, and especially Price, claimed they followed Locke's principles. ${ }^{8} 8$ Richard Price, Political Writings, ed. D.O. Thomas (Cambridge: Cambridge University Press, 1991), 20. On Locke as a major formative influence on Priestley (among others, including David Hartley and Isaac Watts), see Schofield, The Enlightenment of Joseph Priestley, 1-85.View all notes The following discussion will confirm that Price and Priestley went further than Locke, but also show that they also departed from Locke each in his different way. In the end, however, they articulated converging theories of resistance though they were based on different philosophical premises. The analysis will start by general considerations on the Dissenters' views set in contrast with mainstream Whiggism. The following two sections will deal with issues of popular sovereignty, the right of resistance and its conditions in the theories of Price, and then Priestley.

\section{The dissenters and the mainstream Whig resistance theory}

Price's and Priestley's conceptions of resistance must be placed against the backcloth of the Whig resistance theory that had been current since the Glorious Revolution. The Rational Dissenters departed from this dominant Whig ideology, by their vision of seventeenth-century history, secondly, by their defence of popular sovereignty and the people's active role, and thirdly by their redefinition of the criteria for legitimate resistance.

In eighteenth-century Britain, the right of resistance was discussed not just in philosophical terms but especially in terms of British history, with precedents from the seventeenth century always fresh in memory. Eighteenth-century Britain was a post-revolutionary society in the sense that it felt, at least in the dominant whig idiom, that its liberties had been secured (however precariously perhaps) after successful resistance to tyranny. There was thus nothing seditious in asserting the right of resistance; on the contrary Georgian sermons were expected to inculcate sound obedience and a doctrine of limited resistance to tyrants. Most preachers taught that tyrants ought to be resisted but good kings must be obeyed, and of course the Georges fell in the latter category. 'The legitimacy of resistance in extremis was part of the Court-sanctioned ideology of the first two Georges, as much as the validity of the Glorious Revolution and the Act of Settlement which secured it were. ${ }^{-9} 9$ James Joseph Caudle, 'Measures of Allegiance: Sermon Culture and the Creation of a Public Discourse of Obedience and Resistance in Georgian Britain, 1714-1760' (PhD diss., Yale University, 1995), 26. See pages $24-40$ on the theology of limited resistance as a means of inculcating obedience. View all notes While Tories clung to notions of non-resistance and passive obedience which ruled out any resistance against the legitimate monarch, all Whigs recognized the right of resistance, which was a central plank of the party during the Exclusion Crisis and later a justification of the Glorious Revolution.

John Locke's defence of the right of resistance in the last chapter of the Second Treatise of Government (1690) was highly original, conducted as it was in terms of a natural right exerted in case of a 'breach of trust' by the legislative or the executive. Against tory proponents of non-resistance and passive obedience, Locke defended the people's right to active resistance 'when the Legislative, or the Prince, either of them act contrary to their Trust' by acting tyrannically and taking away the people's property, or 'life, liberty, and estate' which the people had entrusted them. Locke listed a number of cases justifying resistance; in particular, 
if the legislative was prevented from assembling or elections were rigged by the executive, if the rule of law ceased or the government took away the people's rights, the people were released from its obedience, reverted to the original liberty it enjoyed in the right of nature and was free to change governors or set up a new polity to defend its property. Though Locke stressed the conservative nature of the people, who would bear much oppression before rising in revolt, he clearly made them the sole judges and vested in them a right of resistance, but also a right to take revolutionary action. ${ }^{10} 10$ John Locke, 'Of the Dissolution of Government', in Two Treatises of Government, ed. Peter Laslett (Cambridge: Cambridge University Press, 1988), 406-28, quotation p.412.View all notes Locke's views were kept alive by the Old Whigs (or Commonwealthmen) in the aftermath of the Glorious Revolution and down to James Burgh's Political Disquisitions (1774-1776). As for the Court Whigs, they never endorsed Locke because of the revolutionary implications of the 'breach of trust', especially if the people (and potentially the populace or mob) was allowed to take arms to redress grievances. ${ }^{11} 11$ On the Commonwealthmen: Caroline Robbins, The Eighteenth Century Commonwealthman (New York: Atheneum, 1968); J.G.A. Pocock, The Machiavellian Moment: Florentine Political Thought and the Atlantic Republican Tradition (Princeton, NJ: Princeton University Press, 1975). On the Court Whigs: Dickinson, Liberty and Property, 5790, 121-62; Reed Browning, Political and Constitutional Ideas of the Court Whigs (Baton Rouge: Louisiana State University Press, 1982).View all notes The Whigs in power refused the doctrine of popular sovereignty and insisted that even though in theory the government was conducted on behalf of the people it did not follow that the people should dictate to the government, still less resist its rulers. While retaining an abstract right of resistance, they played down its practical relevance, insisting that there was no ground for rebelling under the mild administration of the Georges and their Whig ministers. The Glorious Revolution was a unique historical event; it was justified by James II's tyrannical actions but was the exception that proved the rule. Moreover, the Glorious Revolution had led to the final establishment of the constitution; liberty and property were protected as fully as humanly possible, which made any idea of resistance and rebellion against such a beneficent order all the more unjustifiable. ${ }^{12} 12$ Dickinson, Liberty and Property, 130-2.View all notes

The defence of legitimate resistance was tightly knit to that of the Glorious Revolution, hardly a revolution at all because, in the Court Whig interpretation, violence was eschewed and the Revolution did not involve the lower orders but was conducted mainly by noblemen and bishops such as the 'Seven Immortals' who invited William of Orange to England. By contrast, the 'Great Rebellion' of the Puritans against Charles I, and especially the regicide, were wicked and condemnable; those episodes could always serve to castigate the Dissenters as Edmund Burke memorably did in Reflections on the Revolution in France when he compared Price with the Presbyterian divine Hugh Peters, who was praying on the scaffold as Charles I was beheaded. ${ }^{13} 13$ Edmund Burke, Reflections on the Revolution in France, ed. J.G.A. Pocock (Indianapolis, IN: Hackett, 1987), 10. On the conflation between Dissenters, republicans and regicides: Stuart Andrews, 'Cromwell's Ghosts: Republicans and Dissenters', in The British Periodical Press and the French Revolution, 1789-99 (Basingstoke: Palgrave, 2000), 168-78. View all notes

The Dissenters adopted different attitudes to seventeenth-century history. ${ }^{14} 14$ John Seed, Dissenting Histories: Religious Division and the Politics of Memory in Eighteenth-Century England (Edinburgh, 2008).View all notes They expressed their own vision in extensive historiography and in celebrations such as those of the Glorious Revolution by the Revolution Society, founded in London to celebrate the event every 4 November. They did consider the Glorious Revolution as the supreme example of successful resistance and cherished its 
constitutional settlement, but they also tended to see it as an unfinished business, criticizing the shortcomings of the Toleration Act and the growth of corruption that threatened liberty as much as prerogative had before $1688 .{ }^{15} 15$ The prime exponent of this interpretation is Catharine Macaulay, in The History of England from the Accession of James I to That of the Brunswick Line ..., 8 vols (London, 1763-1783) and Observations on a Pamphlet, Entitled, Thoughts on the Cause of the Present Discontents (London, 1770). Price expressed similar views in A Discourse on the Love of Our Country and in a sermon preached in 1759 (Richard Price, 'Britain's Happiness, and the Proper Improvement of It', in Political Writings, 1-13. Priestley cautioned against the growth of corruption after the Glorious Revolution: Joseph Priestley, Lectures on History and General Policy (Birmingham, 1764), 263.View all notes In A Discourse on the Love of Our Country, Price complained that the Revolution had left the parliamentary representation defective and religious freedom inadequate, as the Test and Corporation Acts were still on the statute book. The risk of abuse by the executive was still present. The implication was that post-1689 rulers must be watched, and perhaps sometimes resisted, though Dissenters took great pains to voice their loyalty to the monarchy. ${ }^{16} 16$ H.T. Dickinson, The Politics of the People in Eighteenth-Century Britain (Basingstoke: Macmillan, 1994), 273.View all notes Conversely, they laid claim to the heritage of the patriots who stood up to Charles I (parliamentarians like John Pym or John Hampden) while denying any responsibility in, and sympathy for, the regicide. In 1769 Priestley put the violence and troubles of the Civil War down to Charles I and praised the Dissenters who 'asserted their natural and civil rights', 'bravely opposed force to force, justice to injustice, and at length prevailed.' For all that he denied any involvement of the Dissenters in the regicide and regretted Cromwell's rule. ${ }^{17} 17$ Joseph Priestley, Remarks on Some Paragraphs in the Fourth Volume of Dr Blackstone's Commentaries on the Laws of England, Relating to the Dissenters (1769), 29-30, quoted in Seed, Dissenting Histories, 125. Blackstone had contended that the Dissenters deserved punitive laws because of their turbulent actions in the seventeenth century.View all notes At other moments, though, Priestley provocatively accepted the regicide. In 1791, defending Price against Burke's aspersions, he distinguished Price from the repellent Hugh Peters, but endorsed the regicide, stating that the day of Charles I's execution was 'a proud day for England. ${ }^{, 18} 18$ Joseph Priestley, Letters to the Right Honourable Edmund Burke, Occasioned by his Reflections on the Revolution in France, \&c. The third edition, Corrected (Birmingham: Thomas Pearson; London: Joseph Johnson, 1791), 12.View all notes In 1768, however, Priestley had distanced himself from Cromwell: 'much more may an enemy of Charles the first, be an enemy of Cromwell also. ${ }^{19} 19$ Joseph Priestley, 'An Essay on the First Principles of Government', in Political Writings, ed. Peter N. Miller (Cambridge: Cambridge University Press, 1993), 7. Some Dissenters harboured underground sympathies for Cromwell: Blair Worden, Roundhead Reputations. The English Civil Wars and the Passions of Posterity (Harmondsworth: Penguin, 2001), 215-42. Several Dissenting ministers praised Cromwell and the Saints: Bradley, Religion, Revolution and English Radicalism, 146.View all notes Price, on the other hand, was characteristically cautious and he never expressed himself on the regicide. The difference between Price and Priestley on the Civil War may be one of opinion (Price reproving the regicide and the Commonwealth), or rather, quite possibly, one of character (Price was mild-mannered and avoided giving offence while Priestley had the reputation of a firebrand and relished controversy). In any case, Price was perceived as guilty of regicidal leanings, if only by association, because the Dissenters were always suspect of holding back their opinions and hiding a more radical, regicidal-republican agenda behind praises of resistance in the Glorious Revolution.

While the Court Whigs and the Dissenters fundamentally disagreed about English history, they shared some common assumptions on the exclusion of the poor from the political 
nation. ${ }^{20} 20$ Otherwise, the Dissenters and the Anglicans disagreed over the contours of the political nation, if only because the Dissenters campaigned against the Test and Corporation Acts, which excluded them from political participation.View all notes By 'the people', the Court Whigs meant the political nation, enfranchised men, to the exclusion of women and men of lower social standing, the 'populace' or 'rabble'. Legitimate resistance was undertaken by the 'people', not the populace. Part of the gloriousness of the Glorious Revolution, as was said, was that it involved little or no participation of the rabble. To avoid any misunderstanding, it cannot be said that Price's and Priestley's conceptions of resistance were new because their conception of the people would be more 'democratic'. They probably did not envision 'popular resistance' as a mass movement involving the uneducated and the disenfranchised; that would still belong to the category of the 'mob' in their eyes. Price and Priestley did wish to widen the boundaries of the political nation by enfranchising new social categories, but they did not wish to include servants or manual labourers. Though they were leading participants in campaigns for the repeal of the Test and Corporation Acts that disenfranchised the Dissenters, they were much more cautious when it came to the poor and could not be called democrats in the sense that they did not endorse universal suffrage. They did not even discuss women's suffrage. Price, as will be seen below, encouraged popular participation (including by resistance to rulers), but he never advocated universal manhood suffrage in England, preferring a moderate extension of the franchise. ${ }^{21} 21$ D.O. Thomas, 'Neither Republican nor Democrat', Price-Priestley Newsletter 1 (1977): 49-60.View all notes Priestley did not share Price's views on popular participation and he thought the multitude would remain passive; rather than wishing to enlarge the electorate he proposed a literacy test. $\stackrel{22}{2} 2$ H.T. Dickinson, 'The Representation of the People in Eighteenth-Century Britain', in Realities of Representation. State Building in Early Modern Europe and European America, ed. Maija Jansson (London: Palgrave Macmillan, 2007), 35. Priestley's attitudes to the poor were paternalistic and often harsh: Isaac Kramnick, Republicanism and Bourgeois Radicalism: Political Ideology in Late Eighteenth-Century England and America (Ithaca, NY: Cornell University Press, 1990), 71-98. On the social standing of Rational Dissenters and their ambiguous social position as an excluded minority in a position of power and influence: John Seed, "“A Set of Men Powerful Enough in Many Things": Rational Dissent and Political Opposition in England, 1770-1790', in Enlightenment and Religion, 140-68. View all notes In 1769 he argued that it is not necessary for all men to have a voice in elections; 'it will generally be sufficient if the choice of magistrates be in the majority of those whose circumstances render them above being corrupted'. ${ }^{23} 23$ Priestley, Political Writings, 134.View all notes Neither Price nor Priestley ever entirely explained who he included in the English nation; as for Locke, he was unclear (on purpose, for Richard Ashcraft) as to the social conditions for the franchise. ${ }^{24} 24$ Richard Ashcraft, Revolutionary Politics and Locke's Two Treatises of Government (Princeton, NJ: Princeton University Press, 1986), 583.View all notes Under those conditions, it is not even possible to evaluate whether Price and Priestley were more advanced than Locke on that point.

\section{Richard Price and the rejection of the theory of resistance in extremis}

Richard Price, a Presbyterian minister in Hackney near London, is mainly remembered today for his sermon 'on the love of our country', delivered on 4 November 1789, ostensibly to celebrate the Glorious Revolution of 1688 but praising the French Revolution as a crowning achievement and promise of perpetual peace. In A Discourse on the Love of Our Country, 
Price defined 'the right to resist power when abused' as the second of the three principles secured by the Glorious Revolution:

First, the right to liberty of conscience in religious matters.

Secondly, the right to resist power when abused.

Thirdly, the right to chuse our own governors, to cashier them for misconduct, and to frame a government for ourselves. ${ }^{25} 25$ Richard Price, 'A Discourse on the Love of Our Country', in Political Writings (Cambridge: Cambridge University Press, 1991), 189-90.View all notes

Price's discourse prompted Edmund Burke to retort in Reflections on the Revolution in France, thus igniting the major British controversy around the French Revolution. Burke in fact concentrated on Price's third principle, objecting to 'the right to choose our own governors' (Britain was no elective monarchy), the right to 'cashier [kings] for misconduct' as if they were mere servants, and the right to 'frame a government' in defiance of established, traditional forms. Burke was a consistent Whig and as such he cherished the right of resistance, reaffirming it as lately as $1788 .{ }^{26} 26$ Edmund Burke, who was to be incensed against Richard Price and the Dissenters in 1790, defended the American colonists' resistance to British taxation in the early 1770s, and in 1788, during the trial of Warren Hastings, he also declared that resistance was necessary against a state that failed in its moral duty to protect the people (Richard Bourke, Empire and Revolution. The Political Life of Edmund Burke (Princeton, NJ: Princeton University Press, 2015), 678).View all notes

Burke's criticism of Price's theory and the events in France bear on two aspects of resistance theory. First, he denied that the people could dethrone a king for 'misconduct' or in case power was 'abused': the terms were much too weak, and the implication was that Price placed the threshold of allowable resistance and revolution much too low. Burke recognized that '[k]ings, in one sense, are undoubtedly the servants of the people because their power has no other rational end than that of the general advantage'. It remained that the constitution prescribed that subjects must obey the king and not the other way round. The cashiering of kings was therefore an 'extraordinary question of state'. 'The speculative line of demarcation where obedience ought to end and resistance must begin is faint, obscure, and not easily definable', but there must be a series of tyrannical acts (not a single transgression), a number of 'provocations', and no prospect of improvement to ever justify resistance. ${ }^{27} 27$ Burke, Reflections, 26-7.View all notes For Burke, then, only resistance in extremis was admissible, when the very dissolution of society was threatened, when violence was the only possible option and all other solutions had been tried in vain. In this passage, Burke is close to David Hume, who explained in his essay 'On Passive Obedience', that resistance was permissible in extraordinary cases when obedience would provoke the country's ruin. Hume invoked Cicero's Stoic maxim salus populi suprema lex, the primary law of self-preservation of the state. Such occasions arise 'in extraordinary cases' and the only question remains is 'the degree of necessity, which can justify resistance, and render it lawful and commendable'. Hume 'draw[s] the bond of allegiance very close' and admits the necessity of revolt in extreme cases, but never condones tyrannicide - therefore establishing a hierarchy of acts of resistance. The question of the threshold of resistance must be left unanswered: it can never be ascertained in abstracto and, crucially, it should never be discussed with the general public. Commenting on Charles I's death in the History of England, Hume again reserved the discussion of the conditions of admissible resistance as arcana imperii: 'if ever, on any occasion, it were laudable to conceal truth from the populace': commentators must keep a 
'cautious silence' for fear of weakening the reverence for the government, whose force is founded on opinion. ${ }^{28} 28$ David Hume, 'Of Passive Obedience', in Political Essays, ed. Knud Haakonssen (Cambridge: Cambridge University Press, 1994), 202-3; David Hume, The History of England, from the Invasion of Julius Caesar to the Revolution of 1688 (Indianapolis, IN: Liberty Classics, 1983), 5.544. I have relied on Gilles Robel's critical edition of Hume's Essays: David Hume, Essais moraux, politiques et littéraires et autres essais (Paris: PUF, 2001), 387-8.View all notes The same features appear in Hume's and Burke's accounts of resistance: an admission of the acceptability of resistance in extremis, and a reluctance to discussing the conditions of permissible resistance, especially with the common people given the danger of agitating such questions.

Burke proceeded to explain that France's predicament was not so desperate as to justify a revolution: Louis XVI's monarchy was tolerable and would be replaced by an intolerable revolutionary rule. Secondly, Burke denied Price's contention that the British people had any right to change the form of government in the aftermath of a rebellion. A revolution, in his eyes, was an extremely rare event meant to oust a tyrant that had broken constitutional rules in order to restore them: it had a restorative, conservative purpose. Such was the core meaning of the Glorious Revolution for Burke: it was the ideal moment to effect sweeping constitutional changes, and that is precisely what the Convention Parliament refused to do. ${ }^{29} 29$ Burke, Reflections, 15-19. View all notes

Price's affirmation of the right of resistance, along with the right to refashion institutions (and thus disregard tradition) was at its most flamboyant and memorable in 1789, but it was not the first exposition of his theory of resistance, which dated back to the American, not the French, Revolution. In his best-selling defence of the American colonists in 1776, Observations on the Nature of Civil Liberty, provoking a large-scale debate on natural rights in Britain and America, Price defended the Americans' resistance to the coercive policies of the British government on the ground that it violated their natural rights..${ }^{30} 30$ Price's pamphlets were translated into French, Dutch, German and reviewed in many European periodicals: Yiftah Elazar, 'The Liberty Debate: Richard Price and His Critics on Civil Liberty, Free Government, and Democratic Participation' (PhD diss., Princeton University, 2012).View all notes In the 1776 Observations, and in the Additional Observations published the following year to answer detractors, Price took up Locke's theory of the government as a trust. This served him to assert popular sovereignty and crush the doctrine of the omnipotence of parliament that was used by defenders of the North administration to justify coercion in America. Parliaments, Price wrote,

possess no power beyond the limits of the trust for the execution of which they were formed. If they contradict this trust, they betray their constituents and dissolve themselves. All delegated power must be subordinate and limited. If omnipotence can, with any sense, be ascribed to a legislature, it must be lodged where all legislative authority originates; that is, in the people. ${ }^{31} 31$ Richard Price, 'Observations on the Nature of Civil Liberty, the Principles of Government, and the Justice and Policy of the War with America', in Political Writings, 289. View all notes

Civil magistrates, including the king, are the servants, not the masters, of the people, and must be held accountable. 'A king, in particular, is only the first executive officer, the creature of the law, and as much accountable and subject to the law as the meanest peasant. 32 32 Richard Price, 'Additional Observations on the Nature and Value of Civil Liberty, and the Essentials of a Free Constitution', in Political Writings, 88. View all notes Just like Locke, then, Price 
envisioned that the breach of trust could be committed by the legislative or the executive. ${ }^{33} 33$ Locke, 'Second Treatise', §221, in Two Treatises of Government, 412.View all notes Another parallel can be drawn with Locke's paragraph 221 in the same chapter. Discussing the breach of trust committed by the legislative, Locke listed a number of practices of influence and 'packing' that transparently alluded to Charles II and James II. ${ }^{34} 34$ Richard Ashcraft, Locke's Two Treatises of Government (London: Unwin Hyman, 1987), 214.View all notes Much in the same way, Price details a list of actions by Parliament that may be construed as a breach of trust, such as the 'prolonging of its own duration' (an allusion to the Septennial Act, 1716) or the self-election of the House when co-optation gets the better of the popular vote (in the notorious Middlesex Election of 1768). $\frac{35}{35}$ Price, Political Writings, 28; compare with Locke, 'Second Treatise', §222, in Two Treatises of Government, 412-14.View all notes The drift of Price's argument in those passages from the Observations on Civil Liberty was that a partial, venal House of Commons may be worse than no representation at all for it gave a delusional semblance of liberty that prevented people from rebelling as they should do if they valued liberty properly.

As Jim Caudle noted, Price's fullest exposition of his theory was in a 33-line footnote to a sermon he preached in February 1779. 36 Caudle, 'Richard Price and the Revolution in Resistance Theory', 61-5.View all notes A few weeks before Price had also aired his views in similar terms in a letter to Dr William Adams, the master of Pembroke College, criticizing the views of Josiah Tucker, who allowed of permissible resistance only in extreme cases of oppression. 37 Richard Price to Dr William Adams, Monday, 28 December 1778, in The Correspondence of Richard Price, gen. ed. W. Bernard Peach and D.O. Thomas (Durham, NC: Duke University Press; Cardiff: University of Wales Press, 1983-94), 2.31-33.View all notes Price's preaching on a fast day set apart to pray for British success against the Americans, was in itself an act of resistance since Price criticized the war and justified the Americans. 3838 Richard Price, A Sermon, Delivered to a Congregation of Protestant Dissenters, at Hackney, on the 10th of February Last, being the Day Appointed for a General Fast. By Richard Price, D.D. F.R.S. The Second Edition. To Which Are Added, Remarks on a Passage in the Bishop of London's Sermon on Ash-Wednesday, 1779 (London, 1779).View all notes The sermon rehearsed arguments familiar from the 1776-1777 pamphlets on the rejection of divine right monarchy and Tory notions of passive obedience and non-resistance, in favour of popular sovereignty, the importance of 'an equal and virtuous representation of the people' and the accountability of monarchs and parliaments. $\frac{39}{39}$ Price, A Sermon (1779), 20, emphasis in the original.View all notes The significance of Price's theory of resistance in this sermon is that it departs from what Caudle calls the theory of 'resistance in extremis', according to which, in Price's words, 'resistance can be justified only in cases of extreme oppression.' Such a doctrine, he contends, 'has lost the world its liberty', because men have tended to act too late (out of 'indolence' and lack of union among themselves) so that tyranny has had time to build up its repressive arsenal and has become almost unassailable, hence much bloodshed which could have been avoided had a tyrannizing monarch been resisted earlier. Price turned on its head the traditional notion that resistance must be undertaken as a last-resort measure because of its violent, destructive nature. He thus presented resistance to early manifestations of tyranny as proactive (not defensive as in resistance in extremis) and possibly peaceable. ${ }^{40} 40$ Caudle, 'Richard Price and the Revolution in Resistance Theory', 56.View all notes The implication of Price's theory was that peaceful means of resistance could be found if employed against 'low-level' acts of tyranny, whereas resistance to fullblown tyranny was bound to be violent and bloody. Price's argument, thus, was that by waiting for too long men had encouraged tyrants; rebellions had been bloody while acts of resistance could have been less violent and more effectually checked the progress of tyranny. 
Despite his criticism of resistance in extremis, Price was ready to condone armed resistance, listing successful examples such as small republics of arms-bearing citizens which successfully resisted a mightier monarchy: the Corsicans and France, the Swiss and Austria, and especially the United Provinces, which were born out of successful armed resistance against Spain. ${ }^{41} 41$ Price, Political Writings, 65-6.View all notes Price did not refrain from calling to armed resistance, or at least praising it. 'Freemen will always revolt at the sight of a naked sword', he wrote in Observations on Civil Liberty, in a transparent allusion to American rebellion against British soldiery. ${ }^{42} 42$ Price, Political Writings, 55. In his private letters, Price encouraged his American correspondents to resist the British parliament in more understated ways, possibly because he knew that his mail was monitored by the government. See, for instance, Richard Price to Ezra Stiles, 2 November 1773, in Correspondence of Richard Price, 1.166. View all notes

Not only did Price approve of rebellions past and present, when undertaken on behalf of liberty against authoritarian power, he also wished men had sometimes revolted sooner. He wrote to William Adams that 'a people ought always to keep a jealous eye over the men to whom they have committed the trust of government, and to resist as soon as they think oppression is beginning.' The sermon articulates the same view:

[t]he truth is, that oppression cannot be resisted too soon; and that all the tendencies to it ought to be watched. Had this been always done, tyranny would have been crushed in its birth; and mankind would have been always happy. ${ }^{43} 43$ Price, A Sermon (1779), 19, emphasis in the original.View all notes

Price's optimism appears wildly exaggerated here. However naïve Price might sound, the salient point is that resistance is a prudential duty that starts 'as soon as [the people] think oppression is beginning.' He articulates a duty of resistance, as it were, going well beyond the right of resistance that all Whigs acknowledged. This kind of civic resistance is tied to the notion that the patriot must actively participate in the affairs of the community, exert vigilance over magistrates and criticize them when needed. Price consistently listed those duties among the major characteristics of the patriot, in the 1779 sermon, but also in the 1776 Observations and in the 1789 Discourse on the Love of Our Country, where he wrote: 'the tendency of every government is to despotism, and in this the best constituted governments must end, if the people are not vigilant, ready to take alarms, and determined to resist abuses as soon as they begin. ${ }^{44} 44$ Price, A Sermon (1779), 19-21. A similar description of the patriot is made in 1776 (Price, Political Writings, 30); Price, 'A Discourse on the Love of Our Country', in Political Writings, 187.View all notes Such wishes for a vigilant citizenry hark back to the Country defiance of the men at court; in this Price may well be ranked among the last representatives of the republican, Machiavellian ideology of the Commonwealthmen. ${ }^{45} 45$ Robbins, Eighteenth Century Commonwealthman, 334-45. View all notes

Price's call for early resistance - and probably, then, for more frequent acts of resistance departs from Locke's insistence on the exceptional character of rebellions following a breach of trust. Locke justified resistance and the people's right to overthrow the government but immediately added that the doctrine did not open the door to sedition because the people would bear much oppression before they started to revolt.

Such revolutions happen not upon every little mismanagement in public affairs. Great mistakes in the ruling part, many wrong and inconvenient laws, and all the slips of human 
frailty, will be born by the people without mutiny or murmur. ${ }^{46} 46$ Locke, 'Second Treatise', $\S 225$, in Two Treatises of Government, 415. View all notes

The emphasis in Price is markedly different because he acknowledges the long patience of the people only to deplore it, and he insists that in most cases the people ought to have resisted earlier, 'as soon as they think oppression is beginning'. However, acts of early resistance such as disobeying orders and standing one's ground are a far cry from rebellion and civil war. Subjects in Locke appear to be passively tied by the contract and can change an oppressive government only by way of a revolution. In Price's ideal polity, by contrast, the citizens are bound to obey the law, but have a moral duty of defending their own liberties, which entailed criticizing the magistrates and resisting them if they perceived tyrannical intentions.

Before moving on to examine Joseph Priestley, it is fitting to recapitulate the features of Price's theory, and an internal tension that they entail, which also affects Priestley's. Price went further than Locke by allowing more agency to the 'people' (admittedly, still limited to the enfranchised part of the population), by encouraging a constant popular monitoring of the king, ministers and parliament, and especially by lowering the threshold of resistance, arguing that resistance ought to begin as soon as the people perceive a drift toward despotism. Such a conception would perhaps make resistance more frequent and more commonplace, if government actions routinely trigger acts of resistance. It is arguable that Price's appeal to constant civic vigilance and surveillance of acts that may tend to tyranny can verge on paranoia. Jim Caudle offers a more positive interpretation, speculating that Price 'had redefined resistance into reformism' because coordinated 'popular' resistance (by the political nation, through the channels of parliamentary representation or petitions to the king) could replace bloody resistance. In this view Price's theory of early resistance justifies parliamentary reformism and points the way toward modern constitutions 'which involved paper ballots rather than lead musket shots. ${ }^{47} 47$ Caudle, 'Richard Price and the Revolution in Resistance Theory', 65.View all notes This is a seductive view, but its rather teleological optimism is belied by Price's continued insistence on the recourse to arms. In Observations on Civil Liberty he opposes the valiant, arms-bearing Americans to the slavish Britons; in 1779 he presented the 'musket' as an essential part of the freeman's furniture:

There is a distant country, once united to us, where every inhabitant has in his house (as a part of his furniture) a book on law and government, to enable him to understand his civil rights, a musket to enable him to defend these rights, and a Bible to enable him to understand and practice his religion. ${ }^{48} 48$ Price, A Sermon (1779), 26. For the idealization of the citizen-soldier in Observations on Civil Liberty, see Price, Political Writings, 123.View all notes

Armed resistance can never be ruled out in order 'to defend [civil] rights'. The idealized figure bearing lawbook, musket and Bible is more reminiscent of Country ideology than anticipating modern constitutions (unless we consider the Americans as ancient and the British as irrecoverably modern). It suggests that citizens of a healthy, liberty-loving republic must hold civil magistrates to account, and a necessary consequence is the possibility of armed resistance, which in turn presupposes an arms-bearing, well-trained citizenry.

Political participation and resistance, at least under the form of a threat, are inescapably bound together in Price's doctrine, which therefore possesses the two somewhat contradictory elements that Martin Fitzpatrick identified in a discussion of Priestley's views on resistance: a 'concern for reform and inclusion' through the translation of popular sovereignty into voting rights and popular participation, and on the other hand the 'reassertion of the right to resist 
those in power'. ${ }^{49} 49$ Fitzpatrick, 'Joseph Priestley, Political Philosopher', 116.View all notes Price's doctrine is more liable to this contradiction than Priestley's, since it affirms both popular participation and resistance strongly, while Priestley insists on the latter, but not so much on the former, element.

\section{Joseph Priestley, between Lockean resistance and utilitarian calculus}

Like Price, Priestley held his doctrine of resistance consistently before and during the French Revolution. His laid out his opinions in his Lectures on History and General Policy (which originated in his lectures at the Warrington dissenting academy in the mid-1760s), and more fully in his 1768 Essay on Government. ${ }^{50} 50$ Joseph Priestley, Lectures on History and General Policy (Birmingham, 1764).View all notes Just like Price, Priestley was elated by the French Revolution and was confident it ushered in a period of universal peace, as he wrote in Letters to the Honourable Edmund Burke, a refutation of Reflections on the Revolution in France written within two months after the publication of Burke's book. ${ }^{51} 51$ Schofield, The Enlightened Joseph Priestley, 279, 281; Priestley, Letters to the Right Honourable Edmund Burke: see 1-33 especially on resistance and Price's interpretation of the Glorious

Revolution.View all notes In the Letters, Priestley defended Price and his interpretation of the Glorious Revolution, and restated his own views on resistance. The Lectures on History and General Policy were republished in 1793, without any change on the subject of resistance, $\underline{52} 52$ Joseph Priestley, Lectures on History, and General Policy; To Which Is Prefixed, An Essay on a Course of Liberal Education for Civil and Active Life ... . In Two Volumes (London: Joseph Johnson, 1793).View all notes which suggests a continuity of views until at least a few months before Priestley's exile to America.

Priestley's political theory is very different from Price's but he affirms the right of resistance as forcefully, and somewhat more rhetorically, than Price did. He also departs from Locke and resistance in extremis in his own way. In the Essay on the First Principles of Government, he distinguished political liberty (participation in legislation and government) and civil liberty, while Price confounds the two. For Priestley, the majority of the people are indifferent to politics, and so political liberty matters little, far less than does civil liberty, understood negatively as the right to carry on one's own private affairs unmolested by the state. Priestley's doctrine is utilitarian and relatively indifferent to citizenship as understood (as Price did) as active, constant political participation. For Priestley, the role of the government is to provide for the happiness of the people. 'The good and happiness of the members, that is the majority of the members of the state, is the great standard by which every thing relating to that state must finally be determined.' Political representation matters little provided the government meets this end. ${ }^{53} 53$ Joseph Priestley, 'An Essay on the First Principles of Government', in Political Writings, 1-128, quotation p.13. The quotation is the closest equivalent in Priestley of the formula 'the greatest happiness of the greatest number'. On Jeremy Bentham's possible debt to Priestley, see Robert Shackleton, 'The Greatest Happiness of the Greatest Number: The History of Bentham's Phrase', Studies in Voltaire and the Eighteenth Century 90 (1972): 1461-82. View all notes

In the 1768 Essay, Priestley devoted several pages to the right of resistance. His main statement on the subject takes the form of a passionate rhetorical period: 
if the abuses of government should, at any time be great and manifest; if the servants of the people, forgetting their masters, and their masters' interest, should pursue a separate one of their own; if, instead of considering that they are made for the people, they should consider the people as made for them; if the oppressions and violations of right should be great, flagrant, and universally resented; if the tyrannical governors should have no friends but a few sycophants, who had long preyed upon the vitals of their fellow citizens, and who might be expected to desert a government, whenever their interests should be detached from it: if, in consequence of these circumstances, it should become manifest, that the risque, which would be run in attempting a revolution would be trifling, and the evils which might be apprehended from it, were far less than those which were actually suffered, and which were daily increasing; in the name of God, I ask, what principles are those, which ought to restrain an injured and insulted people from asserting their natural rights, and from changing, or even punishing their governors, that is their servants, who had abused their trust; or from altering the whole form of their government, if it appeared to be of a structure so liable to abuse $?^{54} 54$ Priestley, Political Writings, 18. The sentence is also quoted in Fitzpatrick, 'Joseph Priestley, Political Philosopher', 116 and in Dickinson, Liberty and Property, 197-8.View all notes

While recognizing 'a difference of emphasis as well as of tone', Martin Fitzpatrick judges that this passage 'represents a radicalization of Locke rather than a departure from his thinking' .555 Fitzpatrick, 'Joseph Priestley, Political Philosopher', 116.View all notes Indeed, Priestley uses the Lockean phraseology of 'abuses' and remains, seemingly at least, within the theory of resistance in extremis, justifiable if the government is 'tyrannical' and 'if the oppressions and violations of right should be great, flagrant, and universally resented'. At the end, the expression 'abused their trust' is borrowed from Locke but it doesn't follow that the structure of the argument was Lockean in the 1768 Essay. 56 In 1791, however, Priestley quoted Locke, discussed a tacit 'original compact' and insisted like Locke that the people was naturally conservative and would bear much oppression before revolting (Priestley, Letters to the Right Honourable Edmund Burke, 7-8). View all notes Indeed Priestley did not resort to the fiction of a social contract because his utilitarian premises made it redundant. In The Present State of Liberty in Great Britain and Her Colonies (1769) Priestley bypassed the notions of trust and compact and simply wrote that "nothing hinders that people, thus grossly abused and insulted by their magistrates [...] should strip them of their power, and confer it where they have reason to hope it will be less abused. $\stackrel{57}{57}$ Priestley, Political Writings, 134 5.View all notes

To return to the above-mentioned passage from the Essay, the Lockean breach of trust is at odds with quite a different idea, that of a quantification of good and evil accruing from revolution. If the risk is trifling and involves less evil than those suffered under tyranny, then revolution is worthwhile. This results directly from Priestley's consequentialist ethics and the principle of the greatest happiness of the greatest number: revolution is possible and desirable provided it is not too costly. In theory, theory, then, governments might be toppled even if they are not tyrannical. This utilitarian calculation, therefore, opens a breach in the doctrine of resistance in extremis. A change in government appears as an experiment that may be worth making. Priestley never asserted that resistance to an unsatisfying, though untyrannical, government was both desirable and possible. He was probably cautious and insisted that revolutions were desperate measures taken by an oppressed people (this argument served to justify the French Revolution and ascribe the guilt for the bloodshed to Louis XVI and his minions). $\stackrel{58}{58}$ Priestley, Political Writings, 8, 20.View all notes Although Priestley was careful to stress revolutions were caused by longstanding, unbearable oppression, he also imagined that France could change its political regime frequently in the wake of its 
revolution. He did not flinch at the idea of recurrent regime change following revolutions, considering this less as a tragedy or human drama than as an interesting scientific experiment. Like all oppressed people, he argued, the French would probably fail to see beyond their more direct grievances and the constitutional settlement deriving from their revolution would probably fail to redress all problems. But

if the people in general be well informed and well disposed, they may make many experiments of new forms of government without much inconvenience; and though beginning with a very imperfect one, they may adopt a very good one at the last. ${ }^{59} 59$ Priestley, Political Writings, 8. View all notes

Priestley is vague and optimistic in this evocation of a string of 'experiments of new forms of government without much inconvenience' without ever considering that the transitions could be painful. ${ }^{60} 60$ The new American states born of the American Revolution are 'so many new experiments, of which political philosophers cannot fail to make the greatest use' (Joseph Priestley, Lectures on History and General Policy, to Which Is Prefixed an Essay on a Course of Liberal Education for Civil and Active Life (Birmingham, 1788), 14, emphasis in the original).View all notes This judgment, in retrospect, appears almost flippant knowing that France was to undergo other revolutions and run the whole gamut of régime types until stabilizing as a republic in the 1870 s.

Perhaps the best illustration of this tendency of Priestley's style of reasoning is a paper read to the Manchester Literary and Philosophical Society in 1787 by Thomas Cooper, a personal friend of Priestley's who defended radical opinions forcefully during the French Revolution. $\frac{61}{61}$ Thomas Cooper (1759-1839) gained his radical credentials and his notoriety by writings on parliamentary reform, and especially his travel to Paris with James Watt, Jr., in the Spring of 1792, where he visited the Jacobin Club. Cooper knew Priestley and emigrated to the United States at the same moment in April 1794. On Cooper: Schofield, The Enlightened Joseph Priestley, 322, 329, 333-4; Stephen L. Newman, 'Cooper, Thomas (1759-1839)', Oxford Dictionary of National Biography, Oxford University Press, 2004; online edn, October 2006, http://www.oxforddnb.com/view/article/6231.View all notes Cooper argued much along Priestley's lines. The end of government is the promotion of the happiness of the majority; governors are only given a delegation of power based on the consent of the governed. 'The governors of whatever description in every society upon earth are accountable to the governed. ${ }^{, 62} 62$ Thomas Cooper, 'Propositions Respecting the Foundation of Civil Government', Memoirs of the Manchester Literary and Philosophical Society, 1st series, 3.481-509, quotation p.500. The paper was read on 7 March 1787.View all notes The people have a right to resist any encroachment of despotism, but they are not only reactive. They also have an inalienable right to alter the government or change its rulers whenever they think fit (even without provocation). Cooper was ready to endorse not just the Glorious Revolution but, as Priestley did in some writings, the Civil War of the 1640s. His utilitarian approach conducts him to weigh the sufferings of the revolutionary generation with the benefits of later generations; hence he concludes on the 'benefit of the exertions of the people under the tyrants John, Charles, and James even at this day: the evils of those exertions were confined to a generation or two. ${ }^{63} 63$ Ibid., 507-9, quotation p.509.View all notes In Cooper's version, Priestley's theory of revolutions led to an acceptance of sufferings for 'a generation or two' in the name of the people's liberation; as this 1787 memoir testifies, men like Cooper and Priestley were disposed to welcome the French Revolution with optimism, even if there should be bloodshed in the process. 


\section{Conclusion}

Both Price and Priestley were self-professed disciples of Locke and employed his vocabulary. Both, however, departed from him. The constant vigilance that Price praises as a patriotic duty contrasts with the passive stance that the people appear to adopt in Locke's account, where the people are roused into action only under extreme circumstances. Both Price and Priestley recognize the passivity of the people stated by Locke, but only to deplore it and try to goad the people out of it with their pamphlets. In Locke, it is unclear whether the people, after they have resumed power as a consequence of a breach of trust, will change the governors or the form of government itself. It appears clear that they have a right to do so, since they are sovereign and free to entrust the power in any way they wish. Price and Priestley are more forthright and clearly state that the people may topple a government, punish the governors and remodel the form of government. The idea of régime change, or major constitutional overhaul appalled Burke. Price stated that we the Britons (and any people) had a right to 'frame our government for ourselves'; ${ }^{64} 64$ Price, Political Writings, 190.View all notes the historical possibility was always open. Priestley followed Price on this point. Both were elated by the idea that successful revolution had toppled the French monarchy and they expected other tyrannical governments to follow the same course and be replaced with free polities. It is unclear whether they wished to set up a republican régime in Britain and other European countries. Both Price and Priestley protested that they were loyal to the Hanoverian monarchy and repudiated the idea of a republic in Britain. If they were not republicans in the sense that did not advocate a non-monarchical government, their thought bore some of the features of the classical republican tradition, especially in the case of Price who emphasized the duty of political participation of an arms-bearing citizenry (much more strongly than Priestley did). ${ }^{65} 65$ D.O. Thomas, 'Neither Republican nor Democrat'; Fitzpatrick, 'Joseph Priestley, Political Philosopher', 138-9.View all notes Both men admired the American republican experiment in liberty, Price enthusing as early as 1778 on 'a rising empire, extended over an immense continent, without bishops, without nobles, and without kings ${ }^{66} 66$ Price, 'Introduction to Two Tracts', in Political Writings, 19.View all notes Price's and Priestley's repeated protestations of loyalty to the monarchy may well be defensive and meant to hide a republican agenda; but they might just as well signal a dissociation of the Old and New worlds in their hopes and commitments: a realization that America was free to experiment and republicanism, while old European countries, including Britain, were held back by monarchical and aristocratic mentalities and traditions and could not be expected to transform into republics overnight.

Price and Priestley, therefore, hold quite similar views on resistance. There remain some differences, though some oppositions can be resolved. In particular, Price defended early resistance against the theory of resistance in extremis. On the other hand, Priestley seems to adopt this very theory when he repeated that resistance would only take place as a last resort against despotism. Yet he also argued in terms of utility and the implication of his costbenefit analysis is that early resistance might well be advantageous in some cases. It is unclear to what extent Priestley is a real Lockean, since Locke's conceptual framework of rights, trust and contract is unnecessary in Priestley's utilitarian construction of the polity. Priestley's utilitarianism leads him to a defence of gradual resistance that is congruent with Price's: the people remonstrate to their representatives, or through their representatives to the supreme magistrate, and resistance escalates in case complaints are ignored, until a full-blown revolution breaks out. ${ }^{67} 67$ Priestley, Political Writings, $134-5$.View all notes Price's emphasis on that issue of early resistance to creeping tyranny is different because he is more ready to 
acknowledge the necessity of armed resistance, rather than just action through political and constitutional channels as in Priestley.

The main difference between the two thinkers touches the justification of violence and tyrannicide. Priestley did not hesitate to justify tyrannicide as 'the generous attack of the noble and daring patriot'. The tyrant will be sure to call a missed attempt 'rebellion' but 'that censure cannot make the thing itself less glorious'. ${ }^{68} 68$ Priestley, Political Writings, 23.View all notes Priestley went on to praise Harmodius and Aristogiton, the killers of the Athenian tyrant Hipparchus, and Algernon Sidney and Lord William Russell, who were executed following the Rye House Plot against Charles II in 1683. ${ }^{69} 69$ Priestley, Political Writings, 23. On the rich tradition of writings on tyrannicides: Mario Turchetti, Tyrannie et tyrannicide de l'Antiquité à nos jours (Paris: Presses universitaires de France, 2001).View all notes Price, on the other hand, wrote of the 'right $[. .$.$] to cashier' our governors. { }^{70} 70$ Price, Political Writings, 192.View all notes The word 'cashier' hides the violence of the punishment, except if Price had in mind a bloodless transaction if which a king has his life spared. Price elided the tyrannicide altogether in his writings, though there was no doubt that a sovereign people in a position of punishing a king had both the right and the possibility to execute him. Price might have had sympathies for the figure of the tyrannicide though he never put it in writing. He was a dominant figure in the Society for Constitutional Information and the Revolution Society. At one meeting of the first society in 1782, a song was sung to Harmodius and Aristogiton. In 1788, for the centenary of the Glorious Revolution, the Revolution Society drank a toast to 'the immortal memory of Hampden, Pym, Russell, and Sydney', linking up Charles's parliamentary opponents and the republican martyrs Russell and Sidney. ${ }^{71} 71$ Sir William Jones, An Ode, in Imitation of Callistratus, Sung by Mr. Webb, at the Shakespeare Tavern, on Tuesday the 14th day of May, 1782, at the Anniversary Dinner of the Society for Constitutional Information ([London], [1782]); November, 1788. On the 4th of This Month, Which Was the Hundredth Anniversary of the Glorious Revolution in 1688 ... ([London], [1788]).View all notes There is no saying whether or not Price secretly shared Priestley's admiration for tyrannicides. On this point, it is quite possible that Priestley wrote what Price did not dare to say. ${ }^{72} 72$ Priestley, Political Writings, $134-5$.View all notes

It remains the case that their writings represent the moment when Rational Dissenters most fully expressed a bold doctrine of the right of resistance. It is impossible to sum up in a few words the destiny of Dissent after 1791, when governmental repression and loyalist harassment combined to silence those supporting reform at home or the French Revolution abroad. The period that followed was certainly one of retreat, as far as Dissent was concerned. William Godwin, who stemmed from Rational Dissent and was educated in a dissenting academy, stole the limelight with Political Justice in 1793. Considering that all true change came from the power of truth, he stated that only rational discussion could enlighten men and effect political and social reformations. Godwin therefore rejected violence as a method of political improvement and 'provide[d] us with an account of non-violent change and transition which is in many ways more conservative than Locke in its implications for the justification of violent political action. ${ }^{, 73} 73$ Mark Philp, Godwin's Political Justice (Ithaca, NY: Cornell University Press, 1986), 77.View all notes Price and Priestley were rather bolder than Locke; they brought resistance to the fore and supported resistance in America and in France, though they never called for armed resistance in Britain. Their writings from 17681776 and 1789-1791 provided inspiration for new groups sprung in 1792, especially the London Corresponding Society, which affirmed squarely the people's 'natural and unalienable rights of RESISTANCE TO OPPRESSION, and of SHARING THE GOVERNMENT OF 
THEIR COUNTRY' ${ }^{74} 74$ The London Corresponding Society's Addresses and Resolutions (Reprinted, and Distributed Gratis.) ([London, 1792]), 1.View all notes

\section{Disclosure statement}

No potential conflict of interest was reported by the author.

\section{Notes}

1 The standard works on Dissent are Michael Watts, The Dissenters, 2 vols (Oxford: Oxford University Press, 1978-1995), and James Bennett, History of Dissenters, from the Revolution in 1688 to the Year 1808, 4 vols (London, 1808-1812). There are two biographies of Richard Price: D.O. Thomas, The Honest Mind: The Thought and Work of Richard Price (Oxford: Clarendon, 1977) and Paul Frame, Liberty's Apostle: Richard Price, His Life and Times (Cardiff: University of Wales Press, 2015). On Priestley, see Robert Schofield, The Enlightenment of Joseph Priestley: A Study of his Life and Work from 1733 to 1773 (University Park: Pennsylvania State University Press, 1997) and The Enlightened Joseph Priestley: A Study of His Life and Work from 1773 to 1804 (University Park: Pennsylvania State University Press, 2004).

2 On the American War, see James E. Bradley, Religion, Revolution and English Radicalism: Nonconformity in Eighteenth-Century Politics and Society (Cambridge: Cambridge University Press, 1990). Bradley discusses Dissenting ministers' defence of the right of resistance during the American War (154-8) and Price's influence over some of them (134). On the reception of the French Revolution and the opposition to the French Wars: J.E. Cookson, The Friends of Peace. Anti-war Liberalism in England, 1793-1815 (Cambridge: Cambridge University Press, 1982).

3 The Rational Dissenters rejected Calvinism and its account of the fall of man and the need for regeneration. They embraced Unitarianism (like Priestley at the end of his life) or were on the road to it (like Price, an Arian). Knud Haakonssen, 'Enlightened Dissent: An Introduction', in Enlightenment and Religion: Rational Dissent in Eighteenth-Century Britain, ed. Knud Haakonssen (Cambridge: Cambridge University Press, 1996), 4.

4 Jonathan Israel places Richard Price, Joseph Priestley, John Jebb, William Godwin and Mary Wollstonecraft within the 'radical Enlightenment' in Democratic Enlightenment: Philosophy, Revolution, and Human Rights 1750-1790 (Oxford: Oxford University Press, 2011). See also Anthony Page, John Jebb and the Enlightenment Origins of British Radicalism (Westport, CT: Praeger, 2003).

5 Joseph Priestley and Richard Price, A Free Discussion of the Doctrines of Materialism, and Philosophical Necessity, in a Correspondence between Dr. Price, and Dr. Priestley. To Which Are Added, By Dr. Priestley, An Introduction, Explaining the Nature of the Controversy, and Letters to Several Writers Who Have Animadverted on his Disquisitions Relating to Matter and Spirit, or his Treatise on Necessity (London, 1778).

6 James Caudle, 'Richard Price and the Revolution in Resistance Theory, 1770-1790', Consortium on Revolutionary Europe 1750-1850: Selected Papers (Tallahassee, FL: Institute on Napoleon and the French Revolution, Florida State University, 2000), 55-66; Martin 
Fitzpatrick, 'Joseph Priestley, Political Philosopher', in Joseph Priestley, Scientist, Philosopher, and Theologian, ed. Isabel Rivers and David L. Wykes (Oxford: Oxford University Press, 2008), 116-18.

7 H.T. Dickinson, Liberty and Property: Political Ideology in Eighteenth-Century Britain (London: Weidenfeld and Nicolson, 1977), 197-9.

8 Richard Price, Political Writings, ed. D.O. Thomas (Cambridge: Cambridge University Press, 1991), 20. On Locke as a major formative influence on Priestley (among others, including David Hartley and Isaac Watts), see Schofield, The Enlightenment of Joseph Priestley, 1-85.

9 James Joseph Caudle, 'Measures of Allegiance: Sermon Culture and the Creation of a Public Discourse of Obedience and Resistance in Georgian Britain, 1714-1760' (PhD diss., Yale University, 1995), 26. See pages 24-40 on the theology of limited resistance as a means of inculcating obedience.

10 John Locke, 'Of the Dissolution of Government', in Two Treatises of Government, ed. Peter Laslett (Cambridge: Cambridge University Press, 1988), 406-28, quotation p.412.

11 On the Commonwealthmen: Caroline Robbins, The Eighteenth Century Commonwealthman (New York: Atheneum, 1968); J.G.A. Pocock, The Machiavellian Moment: Florentine Political Thought and the Atlantic Republican Tradition (Princeton, NJ: Princeton University Press, 1975). On the Court Whigs: Dickinson, Liberty and Property, 5790, 121-62; Reed Browning, Political and Constitutional Ideas of the Court Whigs (Baton Rouge: Louisiana State University Press, 1982).

12 Dickinson, Liberty and Property, 130-2.

13 Edmund Burke, Reflections on the Revolution in France, ed. J.G.A. Pocock (Indianapolis, IN: Hackett, 1987), 10. On the conflation between Dissenters, republicans and regicides: Stuart Andrews, 'Cromwell's Ghosts: Republicans and Dissenters', in The British Periodical Press and the French Revolution, 1789-99 (Basingstoke: Palgrave, 2000), 168-78.

14 John Seed, Dissenting Histories: Religious Division and the Politics of Memory in Eighteenth-Century England (Edinburgh, 2008).

15 The prime exponent of this interpretation is Catharine Macaulay, in The History of England from the Accession of James I to That of the Brunswick Line ..., 8 vols (London, 1763-1783) and Observations on a Pamphlet, Entitled, Thoughts on the Cause of the Present Discontents (London, 1770). Price expressed similar views in A Discourse on the Love of Our Country and in a sermon preached in 1759 (Richard Price, 'Britain's Happiness, and the Proper Improvement of It', in Political Writings, 1-13. Priestley cautioned against the growth of corruption after the Glorious Revolution: Joseph Priestley, Lectures on History and General Policy (Birmingham, 1764), 263.

16 H.T. Dickinson, The Politics of the People in Eighteenth-Century Britain (Basingstoke: Macmillan, 1994), 273. 
17 Joseph Priestley, Remarks on Some Paragraphs in the Fourth Volume of Dr Blackstone's Commentaries on the Laws of England, Relating to the Dissenters (1769), 29-30, quoted in Seed, Dissenting Histories, 125. Blackstone had contended that the Dissenters deserved punitive laws because of their turbulent actions in the seventeenth century.

18 Joseph Priestley, Letters to the Right Honourable Edmund Burke, Occasioned by his Reflections on the Revolution in France, \&c. The third edition, Corrected (Birmingham: Thomas Pearson; London: Joseph Johnson, 1791), 12.

19 Joseph Priestley, 'An Essay on the First Principles of Government', in Political Writings, ed. Peter N. Miller (Cambridge: Cambridge University Press, 1993), 7. Some Dissenters harboured underground sympathies for Cromwell: Blair Worden, Roundhead Reputations. The English Civil Wars and the Passions of Posterity (Harmondsworth: Penguin, 2001), 21542. Several Dissenting ministers praised Cromwell and the Saints: Bradley, Religion, Revolution and English Radicalism, 146.

20 Otherwise, the Dissenters and the Anglicans disagreed over the contours of the political nation, if only because the Dissenters campaigned against the Test and Corporation Acts, which excluded them from political participation.

21 D.O. Thomas, 'Neither Republican nor Democrat', Price-Priestley Newsletter 1 (1977): 49-60.

22 H.T. Dickinson, 'The Representation of the People in Eighteenth-Century Britain', in Realities of Representation. State Building in Early Modern Europe and European America, ed. Maija Jansson (London: Palgrave Macmillan, 2007), 35. Priestley's attitudes to the poor were paternalistic and often harsh: Isaac Kramnick, Republicanism and Bourgeois Radicalism: Political Ideology in Late Eighteenth-Century England and America (Ithaca, NY: Cornell University Press, 1990), 71-98. On the social standing of Rational Dissenters and their ambiguous social position as an excluded minority in a position of power and influence: John Seed, "'A Set of Men Powerful Enough in Many Things": Rational Dissent and Political Opposition in England, 1770-1790', in Enlightenment and Religion, 140-68.

\section{Priestley, Political Writings, 134.}

24 Richard Ashcraft, Revolutionary Politics and Locke's Two Treatises of Government (Princeton, NJ: Princeton University Press, 1986), 583.

25 Richard Price, 'A Discourse on the Love of Our Country', in Political Writings (Cambridge: Cambridge University Press, 1991), 189-90.

26 Edmund Burke, who was to be incensed against Richard Price and the Dissenters in 1790, defended the American colonists' resistance to British taxation in the early 1770s, and in 1788, during the trial of Warren Hastings, he also declared that resistance was necessary against a state that failed in its moral duty to protect the people (Richard Bourke, Empire and Revolution. The Political Life of Edmund Burke (Princeton, NJ: Princeton University Press, 2015), 678).

27 Burke, Reflections, 26-7. 
28 David Hume, 'Of Passive Obedience', in Political Essays, ed. Knud Haakonssen (Cambridge: Cambridge University Press, 1994), 202-3; David Hume, The History of England, from the Invasion of Julius Caesar to the Revolution of 1688 (Indianapolis, IN: Liberty Classics, 1983), 5.544. I have relied on Gilles Robel's critical edition of Hume's Essays: David Hume, Essais moraux, politiques et littéraires et autres essais (Paris: PUF, 2001), 387-8.

29 Burke, Reflections, 15-19.

30 Price's pamphlets were translated into French, Dutch, German and reviewed in many European periodicals: Yiftah Elazar, 'The Liberty Debate: Richard Price and His Critics on Civil Liberty, Free Government, and Democratic Participation' (PhD diss., Princeton University, 2012).

31 Richard Price, 'Observations on the Nature of Civil Liberty, the Principles of Government, and the Justice and Policy of the War with America', in Political Writings, 28-9.

32 Richard Price, 'Additional Observations on the Nature and Value of Civil Liberty, and the Essentials of a Free Constitution', in Political Writings, 88.

33 Locke, 'Second Treatise', §221, in Two Treatises of Government, 412.

34 Richard Ashcraft, Locke's Two Treatises of Government (London: Unwin Hyman, 1987), 214.

35 Price, Political Writings, 28; compare with Locke, 'Second Treatise', §222, in Two Treatises of Government, 412-14.

36 Caudle, 'Richard Price and the Revolution in Resistance Theory', 61-5.

37 Richard Price to Dr William Adams, Monday, 28 December 1778, in The Correspondence of Richard Price, gen. ed. W. Bernard Peach and D.O. Thomas (Durham, NC: Duke University Press; Cardiff: University of Wales Press, 1983-94), 2.31-33.

38 Richard Price, A Sermon, Delivered to a Congregation of Protestant Dissenters, at Hackney, on the 10th of February Last, being the Day Appointed for a General Fast. By Richard Price, D.D. F.R.S. The Second Edition. To Which Are Added, Remarks on a Passage in the Bishop of London's Sermon on Ash-Wednesday, 1779 (London, 1779).

39 Price, A Sermon (1779), 20, emphasis in the original.

40 Caudle, 'Richard Price and the Revolution in Resistance Theory', 56.

41 Price, Political Writings, 65-6.

42 Price, Political Writings, 55. In his private letters, Price encouraged his American correspondents to resist the British parliament in more understated ways, possibly because he knew that his mail was monitored by the government. See, for instance, Richard Price to Ezra Stiles, 2 November 1773, in Correspondence of Richard Price, 1.166. 
43 Price, A Sermon (1779), 19, emphasis in the original.

44 Price, A Sermon (1779), 19-21. A similar description of the patriot is made in 1776 (Price, Political Writings, 30); Price, 'A Discourse on the Love of Our Country', in Political Writings, 187.

45 Robbins, Eighteenth Century Commonwealthman, 334-45.

46 Locke, 'Second Treatise', §225, in Two Treatises of Government, 415.

47 Caudle, 'Richard Price and the Revolution in Resistance Theory', 65.

48 Price, A Sermon (1779), 26. For the idealization of the citizen-soldier in Observations on Civil Liberty, see Price, Political Writings, 123.

49 Fitzpatrick, 'Joseph Priestley, Political Philosopher', 116.

50 Joseph Priestley, Lectures on History and General Policy (Birmingham, 1764).

51 Schofield, The Enlightened Joseph Priestley, 279, 281; Priestley, Letters to the Right Honourable Edmund Burke: see 1-33 especially on resistance and Price's interpretation of the Glorious Revolution.

52 Joseph Priestley, Lectures on History, and General Policy; To Which Is Prefixed, An Essay on a Course of Liberal Education for Civil and Active Life ... . In Two Volumes (London: Joseph Johnson, 1793).

53 Joseph Priestley, 'An Essay on the First Principles of Government', in Political Writings, 1-128, quotation p.13. The quotation is the closest equivalent in Priestley of the formula 'the greatest happiness of the greatest number'. On Jeremy Bentham's possible debt to Priestley, see Robert Shackleton, 'The Greatest Happiness of the Greatest Number: The History of Bentham's Phrase', Studies in Voltaire and the Eighteenth Century 90 (1972): 1461-82.

54 Priestley, Political Writings, 18. The sentence is also quoted in Fitzpatrick, 'Joseph Priestley, Political Philosopher', 116 and in Dickinson, Liberty and Property, 197-8.

55 Fitzpatrick, 'Joseph Priestley, Political Philosopher', 116.

56 In 1791, however, Priestley quoted Locke, discussed a tacit 'original compact' and insisted like Locke that the people was naturally conservative and would bear much oppression before revolting (Priestley, Letters to the Right Honourable Edmund Burke, 7-8).

57 Priestley, Political Writings, 134-5.

58 Priestley, Political Writings, 8, 20.

59 Priestley, Political Writings, 8.

60 The new American states born of the American Revolution are 'so many new experiments, of which political philosophers cannot fail to make the greatest use' (Joseph Priestley, 
Lectures on History and General Policy, to Which Is Prefixed an Essay on a Course of Liberal Education for Civil and Active Life (Birmingham, 1788), 14, emphasis in the original).

61 Thomas Cooper (1759-1839) gained his radical credentials and his notoriety by writings on parliamentary reform, and especially his travel to Paris with James Watt, Jr., in the Spring of 1792, where he visited the Jacobin Club. Cooper knew Priestley and emigrated to the United States at the same moment in April 1794. On Cooper: Schofield, The Enlightened Joseph Priestley, 322, 329, 333-4; Stephen L. Newman, 'Cooper, Thomas (1759-1839)', Oxford Dictionary of National Biography, Oxford University Press, 2004; online edn, October 2006, http://www.oxforddnb.com/view/article/6231.

62 Thomas Cooper, 'Propositions Respecting the Foundation of Civil Government', Memoirs of the Manchester Literary and Philosophical Society, 1st series, 3.481-509, quotation p.500. The paper was read on 7 March 1787.

63 Ibid., 507-9, quotation p.509.

64 Price, Political Writings, 190.

65 D.O. Thomas, 'Neither Republican nor Democrat'; Fitzpatrick, 'Joseph Priestley, Political Philosopher', 138-9.

66 Price, 'Introduction to Two Tracts', in Political Writings, 19.

67 Priestley, Political Writings, 134-5.

68 Priestley, Political Writings, 23.

69 Priestley, Political Writings, 23. On the rich tradition of writings on tyrannicides: Mario Turchetti, Tyrannie et tyrannicide de l'Antiquité à nos jours (Paris: Presses universitaires de France, 2001).

70 Price, Political Writings, 192.

71 Sir William Jones, An Ode, in Imitation of Callistratus, Sung by Mr. Webb, at the Shakespeare Tavern, on Tuesday the 14th day of May, 1782, at the Anniversary Dinner of the Society for Constitutional Information ([London], [1782]); November, 1788. On the 4th of This Month, Which Was the Hundredth Anniversary of the Glorious Revolution in $1688 \ldots$ ([London], [1788]).

72 Priestley, Political Writings, 134-5.

73 Mark Philp, Godwin's Political Justice (Ithaca, NY: Cornell University Press, 1986), 77.

74 The London Corresponding Society's Addresses and Resolutions (Reprinted, and Distributed Gratis.) ([London, 1792]), 1. 
